\title{
REVIEW
}

\section{Alan Brill \\ Judaism and Other Religions: Models of Understanding}

(New York: Palgrave Macmillan, 2010), hardcover, xiv + 275 pp.

Paul F. Knitter, Union Theological Seminary

In this book, Alan Brill has set himself a formidable task: not to offer a Jewish theology of religious pluralism (which would be formidable enough), but to collect the building materials for such a theology. He wants to assemble, rather than to construct; to gather, rather than to select. Fortunately, he does not entirely succeed. He does not, because he (or anyone) cannot, keep the two moves entirely separate. While he assembles and gathers, he reveals preferences for construction. That is a big part of the significance, and the charm, of his book.

He first announces the dire situation he hopes to repair. Contemporary Jewish theologians, in contrast to their Christian counterparts, have "sorely neglected" the need to make sense of the perduring fact of religious diversity (p. 8). But to rise to this task, Jewish scholars will have to abide by their tradition's hermeneutical leitmotif: "the criterion of textuality" (p. 11). He explains: "The discussion [about other religions] cannot go forward without a sound grounding in the past texts and engagement with past theological rubrics" (p. 225). This book will take up the task of providing such grounding and such rubrics, mainly from "the rabbinic literature" which provides "the core texts of the Jewish tradition" (p. 41).

Having identified the primacy of "textuality" for any Jewish theology of religions, Brill proceeds, in the bulk of the book, to show how the multiple voices and visions in the Bible, rabbinic thought, and Jewish tradition can be categorized, sometimes neatly and sometimes awkwardly, within the categories used by Christian theologians of religions: as exclusivist, inclusivist, pluralist, or (here he adds an ambiguous new category) universalist. But he makes it clear from the beginning (though he may not be so clear at the end) that he is not out to privilege one model over the others. Indeed, he proposes these models as a wardrobe from which Jews can choose depending on the occasion: "As dutiful Jews we need not always choose one position over the others...[we can] shift our stories between inclusivist, exclusivist, and pluralist positions in accordance with our own inner dialogues, external contexts, and practical situation" (pp. 21-22).

Although he insists on the fluidity and relativity of all the models, he is quite clear on locating people and texts within them:

- Exclusivist views, which hold the Torah and Judaism as "the sole revealed religion" and tend to classify other religions as demonic and idolatrous, are found especially in juridical appraisals in the halakhah, as well as in the "demonic dualism in the Kabbalah." Brill notes that such castigating assessments were often forged in historical contexts of persecution and then raised to "metaphysical abstraction" (pp. 151, 163).

- Inclusivists are inclined to view other religions as "part of a greater entity of religion" and to see them as playing "providential role[s]" (p. 97). While acknowledging other religions, they hold to 
Jewish particularity, which sometimes is understood to supersede the others. He finds this view represented by Yaakov Emden (1697-1776) and Abraham Isaak Kook (1865-1935).

- Although Brill offers two different chapters on universalist and pluralist perspectives, in the end, it is somewhat difficult to identify defining differences between them. Universalists in his view seem to affirm the validity of many religions based on their commonalities, while pluralists do the same in view of diversity: "Universalism opens us to the natural human elements in coming toward God and the brotherhood of man [sic], the basis of religious humanism. Pluralism lends dignity to human difference and diversity" (p. 225). He offers a line-up of contemporary Jewish pluralists-David Hartman, Zalman Schachter-Shalomi, Irving Greenberg, Elliot Dorff, Michael Kogan, and Jonathan Sacks-and suggests that they represent a "camouflaged universalism" (pp. 130, 148).

Although Brill suggests that we will have to wait for a future book for a clearer statement of his own views (his Judaism and the World Religions has subsequently appeared), in his final chapter he seems to opt for what looks like a pluralist model for a contemporary Jewish theology of religions. Given the "new religious landscape in America" and in much of the world calling for interreligious co-existence and collaboration; given the changing attitudes of Christians toward Jews (in which churches are "moving from persecutor to greatest friend" of Jews [p. 235]); given the greater security and "sense of at-homeness" that Brill sees as necessary for any positive Jewish view of other religions (p. 169); and given this general state of the world and of Judaism, Brill boldly announces that:

It is time for Judaism to take its rightful place as part of the global parliament of religions ...It is time for us to put aside the role of a nation of victims that we assumed due to circumstances of history, and return to the role played by our ancestors Abraham, Isaac, and Jacob: heroes of Divine history...(p. 231).

Instead of tagging his theology of religions as "pluralistic," he calls it "hospitable." Hospitality towards those of other religious ways is the moral demand on contemporary Jews, at least in the United States: "Tolerance is not enough....we need hospitality" (p. 226). And hospitality calls for "conversation, graciousness, listening and mutual respect...genuine openness to the other" (pp. 227-28). Such a pluralistic hospitality toward others will in no way diminish or threaten Jewish identity and particularity, but it will require "Moving forward... beyond provincialism toward understanding Judaism as a faith among faiths" (p. 239).

Brill has done a notable, indeed a remarkable, service in this book, primarily for his fellow Jewish believers and theologians but also for Christians, Muslims, and others engaged in interreligious dialogue. He has admirably carried out the formidable task he assigned himself-to take the necessary first step of gathering the abundant sources for a Jewish theology of religions. But he has also made clear some of the next steps that those sources make possible, or even demand. 